\title{
A TRITERPENE GLYCOSIDE FROM Dianthus inacotinus
}

\author{
V. Ya. Chirva and P. K. Kintya
}

UDC $547.913+547.918$

In spite of the intensive investigation of the triterpene glycosides of the family Caryophyllaceae [13], many representatives of it have still remained unstudied. Thus, for example, there is no information whatever in the literature on the saponins of Dianthus inacotinus.

A methanolic extract from the roots of this plant contained one glycoside, which we isolated by chromatography on a column of silica gel in the butan-1-o1-ethanol-water $(10: 2: 5)$ system in preparative amount. In its melting point $\left(136^{\circ} \mathrm{C}\right)$, specific rotation $\left([\alpha]_{\mathrm{D}}^{20}+35^{\circ}\right.$ (c 1.3; methanol)), and chromatographic mobility the compound obtained was identical with saponaside A, which we have isolated previously from Saponaria officinalis L. [4].

The substance was additionally identified by its methylation and the tetrahydroaluminate cleavage of its permethylate. The reduced glycoside was found by thin-layer chromatography in benzene-acetone (2: 1) to contain 2,3,4-tri-O-methyl-D-glucopyranuronic acid, and among the methanolysis products of the oligosaccharide we identified, in the presence of sugars of known structure, 2,4-di-O-methyl-D-sorbitol and 2,3,4,6-tetra-O-methyl-D-glucopyranose. In the periodate oxidation of the saponin, the glucose was not affected. On this basis, we concluded that Saponaria officinalis L. (bouncing bet) and Dianthus inacotinus contain one and the same saponin.

\section{TERAT URE CITED}

1. V. Ya. Chirva and P. K. Kintya, Khim. Prirodn. Soedin., 6, 214 (1970).

2. N. K. Kochetkov, A. Ya. Khorlin, and Yu. S. Ovodov, Zh. Obshch. Khim., 32, 782 (1962).

3. Zh. M. Putieva, L. G. Mzhel'skaya, E. S. Kondratenko, and N. K. Abubakirov, Khim. Prirodn. Soedin., $\underline{6}, 486(1970)$.

4. V. Ya. Chirva and P. K. Kintya, Khim. Prirodn. Soedin., $\underline{5}$, 188 (1969).

Institute of Chemistry, Academy of Sciences of the Moldavian SSR. Translated from Khimiya Prirodnykh Soedinenii, No. 4, p. 532, July-August, 1971. Original article submitted March 4, 1971.

- 1973 Consultants Bureau, a division of Plenum Publishing Corporation, 227 West 17th Street, New York, N.Y. 10011. All rights reserved. This article cannot be reproduced for any purpose whatsoever without permission of the publisher. A copy of this article is available from the publisher for $\$ 15.00$. 